\title{
DIMENSI SOSIOLOGIS SUFISME DALAM LINTASAN SEJ ARAH: Dari Asketisme Sufisme-Klasik hingga Post-Modernisme
}

\author{
Ifa Nurhayati*
}

\begin{abstract}
A bstract: Sufism has evolved from time to time and from society to another by presenting itself in various forms and ways. By virtue of its tenets, Sufism has influenced many societies and different cultures. Sufis have played a significant role in their respective societies as religious mentors or else as political advisors. Many of them have otherwise stood in opposition to the political authority and proposed a better way of running the society. Across history, Sufism has shown itself as a dynamic and innovative social and religious force. In the final analysis, Sufism cannot be ignored as the major contributor to the structure of Islamic civilization. In the meantime, the social and religious malaises that we witness in modern time have called Sufism into play. Modernism has produced an unbalanced life, triggering the absolutistic way of life where a man is aware only of his physical dimension and ignoring his spiritual inner being. Here, Sufism can play its important role. The modern intellectual paradigm that puts more emphasis on empiricism and rationalism and produces as a result the positivistic mode of thinking has paved the way for Sufism to occur and recur as the dominant player in the domain of man-personality building. This paper is concerned with this issue and other related problems. Putting in mind that Sufism has its social dimension the paper believes that it has something to offer for modern men living in time of great uncertainty.
\end{abstract}

Keywords: Sufism, social dimension, asceticism, contemporary Sufism

\section{Latar Belakang Masalah}

Pro kontra cara pandang (outsider maupun insider) masyarakat, terhadap keberadaan sufisme muncul sejak istilah tersebut belum akrab di telinga masyarakat. Kompleksitas dan pluralitas cara pandang masyarakat terhadap istilah sufisme ini tentu saja tidak luput dari perbedaan ideologi dan cara pandang mereka terhadap term sufisme tersebut. Sebagian mereka menilai bahwa sufisme identik dengan orang gila, peminta-minta atau orang jalanan (kere: J awa). Cara pandang seperti ini, sufisme hanya dilihat dari dimensi fisikalnya saja. Sebagian yang lain menilai bahwa sufisme tidak ubahnya seperti sakr (pemabuk), kafir, shirik, karena argumentasiargumentasi metafisikanya yang sulit ditangkap oleh nalar normal layaknya masyarakat yang beragama. Sementara sebagian yang lain menilai bahwa sufisme adalah mereka yang memiliki sikap kritis dan sulit diatur, mengingat hampir keseluruhan pola hidup sufisme didesain sebagai kelompok oposan yang senantiasa mengkritisi roda kepemimpinan para penguasa pada saatnya. Selain itu, yang lebih akrab di telinga masyarakat Muslim, bahwa mereka diklaim sebagai komunitas yang menghambat kemajuan zaman karena cara pandangnya yang sangat skeptis dan eskatologis.

H anya saja selain cara pandang dengan nada negatif tersebut terdapat juga cara pandang positif yang sangat berbeda dengan cara pandang sebelumnya. Sufisme dalam hal ini dianggap

\footnotetext{
${ }^{*}$ Staf Pengajar UIN Malang.
} 
sebagai sekte yang memiliki komitmen ideal untuk menolak kejahatan dan senantiasa berpihak pada kebenaran. Landasan paradigmatik inilah yang memotivasi para sufisme untuk tetap tegar dan berani melawan para penguasa yang lalim dan dlalim. Sebab cara pandang demikian merupakan bagian dari ajaran spiritualitasnya yang senantiasa dikembangkan secara intens.

Pro kontra cara pandang inilah yang pada giliranya memunculkan penilaian-penilaian pejoratif dan subyektif dari kalangan masyarakat Muslim pada khususnya dan non Muslim pada umumnya sesuai dengan sudut pandang latar ideologi dan pemikirannya masing-masing. $\mathrm{Hal}$ ini menggambarkan bahwa selama ini penilaian masyarakat terhadap sufisme dalam konteks historis belum diposisikan pada penilaian obyektif. Penilaian yang berusaha memasuki ruang dan emosi mereka secara terbuka. Bukan sebaliknya, yaitu penilaian yang senantiasa melibatkan tendensi-tendensi relegio-politik, seperti munculnya klaim perilaku bid'ah, khurafat dan tahayyul, yang senantiasa dialamatkan kepada sufisme, karena pola hidupnya yang cenderung tidak mengikuti aturan-aturan shar'i $>0$ leh karena itu sebelum lebih jauh makalah ini mengungkap tentang bagaimana karakteristik kehidupan masyarakat kontemporer termasuk juga sikap sufisme di tengah kehidupan kontemporer, akan dipaparkan lebih dahulu tipologi sufisme serta yang melatarbelakangi kemunculannya.

\section{Tipologi Latar Belakang Munculnya G erakan Sufisme}

\section{Sufisme Klasik}

Tradisi sufisme di kalangan masyarakat dunia Islam telah popular sejak akhir abad II Hijriyah. ${ }^{1}$ Sekalipun secara formal istilah ini belum dikenali oleh masyarakat Muslim ketika itu, namun substansi sufisme ini pada hakikatnya identik dengan model keberagamaan yang dahulu akrab dengan sebutan zahid dan 'abid, yaitu tradisi asketisme yang biasa terlihat di serambi masjid Madinah. Tradisi keberagamaan para zahid dan 'abid inilah yang pada gilirannya memanifestasi menjadi tradisi sufisme. ${ }^{2}$

Tradisi keberagamaan para zabid dan 'abid ini cenderung lebih menekankan pada permasalahan-permasalah akhirat (asketisme) dan abai terhadap keasyikan dunia. Munculnya sikap keagamaan ini terutama karena dipicu oleh tiga faktor, Pertama: sikap hedonis para khilafah, gaya kehidupan glamor-profanistik dan materialistik-konsumeristik. Lebih dari itu sikap ini telah meluas dan menginspirasi para penguasa daerah. Munculnya sikap keagamaan asketis ini dengan kata lain adalah reaksi terhadap model kehidupan penguasa yang sekuler. Inilah bentuk protes sufisme terhadap pemerintah dengan tetap menyajikan sikap etis dan spiritualis yang dibingkai dengan kearifan ruhaniah. Kedua: sikap radikal dari penguasa (Khawarij) dan dampak polarisasi politik yang ditimbulkannya. Sikap kekerasan penguasa ini tanpa terasa telah menutup ruang para zahid dan 'abid untuk mengekspresikan kesalehan individualnya (vertikal) maupun sosialnya (horisontal) dalam suasana kedamaian ruhaniah dan cinta sesama. Bentuk pelarian dari sikap ini adalah 'uzlah kolektif. Ketiga: kodifikasi hukum Islam (fiqih) dan perumusan ilmu kalam (teologi) yang berpijak pada kerangka

\footnotetext{
${ }^{1}$ Abd al- Karim al-Q ushayiri>al-Risalah al-Q usyairiyah (Kairo: tp, $1330 \mathrm{H}$ ), 138.

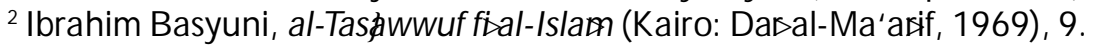


paradigma dialektika-rasional. Landasan paradigma inilah yang pelan-pelan telah menggeser dimensi etik dari praktik keagamaan itu sendiri. Trend keagamaan ini pula yang akan menyebabkan hilangnya ruh keagamaan (spiritual). Dengan kata lain agama yang hanya mengandalkan bentuk tanpa jiwa. Karena suasana hukum dan teologi yang yang kering tanpa jiwa, dihadapkan pada dominannya suasana moral keagamaan ketika itu membuat para zuhhad mencurahkan perhatiannya pada moralitas. Sikap inilah yang memacu adanya pergeseran tradisi asketis menuju tradisi sufis. Mereka yang tergolong pada priode ini adalah Hasan al-Bashri (w. $110 \mathrm{H}$ ) melalui doktrin zuhud, khawf, dan raja'nya, Rabi'ah al-Adawiyah (w. $185 \mathrm{H}$ ) dengan ajaran mahabbahnya, Ma'ruf al-Kharki $(w .200 \mathrm{H}$ ) dengan ajaran konsepsi al-Shawqnya. ${ }^{3}$ Dilanjutkan kemudian oleh Dzural-Nun al-Mishriłw. $245 \mathrm{H}$ ) dengan konsepsi spiritual al-maqamat dan al-ahwalmya (psiko-gnostik). ${ }^{4}$ Sejak berkembangnya secara luas konsepsi ini maka berarti pemilahan secara tegas tentang tasawuf dan kesalehan asketis terlihat sangatjelas.

Paham keagamaan asketis tersebut pada hakikatnya merupakan bibit awal bagi lahirnya sufisme sebagai peradaban dalam Islam. la juga merupakan aliran keagamaan yang menandai kegiatan spiritual pada fase awal Islam. O leh karenanya fase awal Islam itu juga dikenal dengan fase asketisme. Fase ini berlangsung hingga akhir abad II H. Peralihan dari akhir abad II H memasuki abad III H inilah yang secara formal telah merubah tradisi asketisme ke dalam tradisi sufisme, dari zahid, 'abid menjadi sufi. Dampak peralihan trend keagamaan ini telah memunculkan para mutasawwif terkemuka pada zamannya, antara lain adalah, Abu Yazid al-Bistạmi (w. $260 \mathrm{H}$ ) dengan doktrin ittihad melalui konsep al-fana'^nya, yakni sikap meleburnya sifat-sifat kemanusiaan (nasut) ke dalam sifat ilahiyah (lahut) sehingga terjadi penyatuan antara manusia dengan tuhannya dalam al-fana's

2. Sufisme Ortodok

Tipologi sufisme ortodok ini kemunculannya sedikit agak berbeda dengan sufisme klasik. Gerakan sufisme ortodok ini lahir semata-mata karena pengaruh politik. Terjadinya perseteruan politik antara kaum Sunni>dengan Shi'i $>$ abad III Hijriyah telah melahirkan sufisme versi ortodoks. Sufisme ortodok dirintis oleh tokoh sufi bernama Harith al-Muhasibi (w. $243 \mathrm{H}$ ). Munculnya sufisme ortodoks tidak lain adalah upaya menegakkan kembali warisan kesalehan sufi terdahulu, yakni di kalangan para sahabat dan generasi setelahnya yang tetap menerapkan sisi-sisi keagamaan yang lahiriyah. Sehingga jurang pemisah antara Islam ortodok dan kesucian sufisme tetap berada dalam wilayah Islam yang murni. Sejak itulah, abad III H ditengarahi sebutan sufisme ortodok muncul, dan sekaligus momentum ini menjadi gerakan pertama dalam gerakan pembaruan sufisme. ${ }^{5}$ U paya rekonsiliasi pembaruan yang dirintisnya ini dilanjutkan oleh al-H arraj (w. $277 \mathrm{H})^{6}$ dan al-J unaid al-Bagdadi (w. $297 \mathrm{H}$ ) dengan mencoba menawarkan konsep tasawuf yang kompromistik, yaitu antara sufisme dengan kelompok

\footnotetext{
${ }^{3}$ R.A. Nicholson, The Mystic of Islam (London: Kegan Paul,1966),3-4.

${ }^{4}$ al-M aqamatradalah jenjang pelatihan dalam sistem pembinaan moral calon sufi sehingga terkondisi dalam dirinya nilai-nilai dari setiap jenjang. Sedangkan al-ahwalıadalah kondisi jiwa yang muncul sebagai wujud rahmat Allah, usai melaksanakan satu tingkat maqam.

${ }^{5}$ Rivay Siregar, Tasawuf: Dari Sufisme Klasik ke Neo Sufisme (J akarta: Raja G rafindo Persada, 2002), 301-302. ${ }^{6}$ Bernd Radtke, "Konsep Wilayah dalam Sufisme A wal" dalam Warisan Sufi: Sufisme Persia K lasik dari Permulaan Hingga Rumi (700-1300). Terj. G afna Raizha Wahyudi (Yogyakarta: Pustaka Sufi, 2002), 563.
} 
ortodoks (salafiyah). Cara pandang ini tentu memiliki prospektif pola integrasi antara kesadaran mistisisme dengan formalisme (shariłah).

Upaya tajdid ini tanpa terasa memperoleh sambutan yang sangat luas dari kalangan para pemerhati tasawuf, antara lain dengan munculnya para penulis sevisi yaitu al-Saraj dengan karyanya al-Luma', al-Kalabadhi dengan karyanya al-Ta'aruf li al-Madhdhab alTasawwuf, al-Qushayri dengan karyanya al-Risalah. Karya ketiganya berisi metode mengembangkan sikap sufisme moderat yang senantiasa menunjang ide-ide ortodoks.

Selain 3 faktor di atas, sikap keagamaan para guru sufi pada priode ini muncul karena dimotivasi oleh mewabahnya gerakan pemahaman spekulatif-teoretis murni yang menyentuh pada wilayah kesatuan wujud. ${ }^{7}$ Suatu pemahaman yang lebih menekankan pada wilayah dominasi ego, suatu pemikiran filsafat yang diperoleh melalui akal. Sementara mereka lebih menekankan pada siratan penglihatan hati. ${ }^{8}$ Keyakinan kebenaran melalui filsafat bagi mereka hampa akan keuntungan spiritual yang sesungguhnya. la akan membawa seseorang, baik secara sosial maupun moral tersesat. Karena seseorang akan dengan mudah menyelewengkan filsafat untuk kepentingan ego personal. ${ }^{9}$ Trend keagamaan ini direpresentasi oleh Abu Sa'id Ibn Abi al-Khair (w.440 H). ${ }^{10}$

Gerakan sufisme di atas, menemukan puncak keemasannya kurang lebih pada abad 5 Hijriyah, yaitu melalui gagasan monumental al-G hazali (w. $503 \mathrm{H}$ ). G erakan al-G hazali ini terutama bermaksud mencegah berkembang suburnya sufisme teosofi atau sufisme falsafi/ Shi'i yyang mendapatkan sambutan positif di era tersebut. Padahal sikap dan pemahaman keagamaan mereka menurut versi sufisme ortodoks dapat menyelewengkan aqidahnya. Atas dasar ini al-G hazali berusaha merumuskan konsepsi-konsepsi yang dapat menjawab aspirasi kedua belah pihak, yaitu sufisme dan ortodoksi Islam. Konsepsi ma'rifah dan hakikatlah yang mampu memberikan jawaban antara kubu isi dan lahir.

Sejak itu pulalah sufisme ortodoks memperoleh tempat yang terhormat dalam konteks sejarah pemikiran Islam. Dengan lahirnya para sufi terkemuka ini membawa dampak secara konseptual dan tekstual terhadap pemahaman sufisme tersebut. Atas dasar itulah konsep sufisme berkembang secara dinamis hingga menyentuh pada ranah intuisi, dhawq maupun al-kashf. ${ }^{11}$

\section{Sufisme Teosofi}

Tipologi sufi yang menekankan nalar falsafi ini jauh sebelum kemunculannya telah dicurigai eksistensinya oleh sufisme ortodok. Trend sufisme model inilah yang dikhawatirkan al-G hazali akan mendominasi trend pemikiran Islam ketika itu. H anya saja gerakan pemikiran ini ternyata belum bisa menandingi derasnya perkembangan nalar sufisme ortodok yang digagasal-G hazali. Namun demikian, betapapun tingkatpopularitas gagasan ortodoksi sufisme al-G hazali, pada suatu saat ia juga mengalami masa-masa keredupannya. Pada momentum itulah Ibn 'A rabi dengan menggunakan term yang sama, yaitu ma'rifat - sebagaimana term

J] avad N urbakhsh, "C iri-ciri Utama Sufisme dalam Pereode A wal Islam" dalam Warisan Sufi: Sufisme Persia Klasik, 1.

${ }^{8}$ Ibid., 1.

9 Ibid., 2.

10 Ibid.,2.

${ }^{11}$ Abu al-WafaSal-Ghanimi al-Taftazani, Madkhal ila al-Tasłwwuf (Kairo: Dasal-Thaqafah, 1974), 80-82. 
yang dipakai oleh al-Ghazali-tidak saja bermaksud mengungkapkan konsep kesatuan manusia dengan Tuhannya (seperti halnya Abu Yazid al-Bistąmi), namun juga bermaksud menyajikan gagasan-gagasan isoterik-filosofik. Dengan kata lain bermaksud membuat pencerahan pemikiran yang merelasikan antara fenomena alam yang pluralistik dengan Tuhan sebagai prinsip keesaan yang melandasinya.

Perhelatan wacana sufisme di kalangan Muslim marak kembali ketika konsepsi Ibn 'A rabi (w. $638 \mathrm{H}$ ) tentang wahdat al-Wujud terlihat membumi kembali. Konsepsi ini dianggap oleh para pemikir Islam sebagai sikap keagamaan yang ke luar dari Islam (kafir). Paham ini dikategorikan sebagai paham pantheisme (paham serba Tuhan). Paham ini ditengarahi adalah paham yang menelusupkan kerangka nalar filosofis ke dalam ranah sufisme, baik yang bersifat epistemologis maupun postulat-postulat filsafat Yunani, terutama neo-platonisme.

4. Neo-Sufisme

Agaknya gerakan sufisme teosofi Ibn 'Arabi ini mendorong upaya-upaya baru Ibn Taimiyah dan Ibn Q ayyim al-J auzi pada abad $8 \mathrm{H}$ melanjutkan proyek pemikiran al-G hazali. Gerakan kedua tokoh ini secara terang-terangan menolak doktrin monism (wahdlat al-wujud) Ibn 'A rabi sekaligus berupaya mencegah berbagai motif ritual para sufis yang berkembang pada waktu itu. Atas dasar inilah Fazlur Rahman menyebut Ibn Taimiyah sebagai perintis gerakan Neo-Sufisme ini. ${ }^{12}$

Upaya-upaya pengembalian sharisah dan pengimplementasiannya di kalangan masyarakat Islam sufis terlihat tanda-tanda keberhasilannya. Melalui upayanya yang maksimal itu, tepatnya pada Abad $8 \mathrm{H}$ gerakan sufisme asketis yang abai terhadap sharisah mulai terlihat tanda-tanda kelesuhan dan kemandekannya. Indikasi itu terlihat bahwa sejak itu tidak ada konsep-konsep sufisme yang baru dan orisinil. Yang berjalan adalah ulasan-ulasan dari konsep lama atau peniruan. Sementara dalam tataran aplikasi pengamalan sufisme mampu berjalan semarak namun lebih didominasi oleh tarekat atau institusi sufi yang lebih menampakkan aspek ritualitasnya, dan bukan pada substansinya.

Inilah salah satu penyebab suramnya cahaya sufisme di era kemudian. Tidak hanya itu menurutnya model sufi inilah yang kerap kali dituding sebagai biang kerok penyebab kemunduran umat Islam. Karena alasan ini pulalah Ibn Taimiyah mengkategorikan kaum sufi itu ada tiga, pertama, sufi hakikat, yaitu mereka yang sungguh-sungguh mencari kebahagiaan spiritual. Kedua, sufi rizqi, mereka yang tinggal di asrama pondokan yang mengharapkan uluran tangan dari orang lain. Ketiga, sufi formalitas, yaitu mereka yang bergaya sufi tetapi jiwanya tidak sepenuhnya terikat oleh sufisme. ${ }^{13}$

Tanpa terasa cara pandang Taimiyah dan Ibn Qayyim ini mengidealkan adanya pola integrasi antara taswawuf dan shariłah sebagaimana yang pernah digagas al-G hazali. Namun demikian sufisme yang berkembang ketika itu hanya dalam tataran ritualitas belaka, sikap keagamaan yang asketis dan abai pada kehidupan sosial.

\footnotetext{
${ }^{12}$ Rivay Siregar, Tasawuf: Dari Sufisme Klasik, 312.

${ }^{13}$ Ibn Taimiyah, al-S fufiyah wal Fuqara, di edit oleh Rasyid Ridla, al-Manar, Kairo, 1348 H . : 17-22
} 


\section{Menelusuri Corak Sufisme di Tengah Kehidupan Kontemporer}

1. Karakteristik, Peluang dan Tantangan Kehidupan Kontemporer

Inspirasi munculnya Neo-Sufisme di dunia Islam ditengarahi hampir senada dengan motif bangkitnya semangat keagamaan sebagai penolakan terhadap sikap penuhanan sain dan teknologi modern. Modernisme yang sarat dengan nilai-nilai empirisme, rasionalisme dan positivisme telah dinilai gagal oleh kelompok ini untuk menyajikan menu kehidupan bagi manusia, yaitu kehidupan yang gersang dari nilai-nilai spiritualitas. Manusia hanya dimaknai sebagai makhluk jasmani yang hanya memerlukan kebutuhan-kebutuhan fisikal saja. Ia tidak dipahami sebagai makhluk dua dimensi, jasmani dan ruhani, fisik dan psikis, rasio dan emosi, demikian seterusnya. Oleh karenanya, sikap kehidupan yang demikian dirasa kurang mampu memberikan jawaban yang seimbang bagi manusia. Mereka merasakan kehampaan dan kegersangan dalam kehidupannya. Mereka ingin kembali ke alam dunianya yang penuh dengan kebebasan yang kini telah tereduksi oleh arus dunia kemodernan dengan seperangkat tata nilainya.

Inilah yang pada gilirannya melahirkan anggapan kuat bahwa agama betapapun tetap menjadi entitas yang tidak bisa luput dari kebutuhan manusia modern di manapun mereka berada. Sebab bagian dari fungsi dan peran agama itu sendiri adalah memberikan makna bagi kehidupan manusia, utamanya pada ranah-ranah nilai spiritualnya.

Kegagalan modernisme ini telah mengantarkan manusia hijrah ke pilihan sikap keagamaan barunya, yang memiliki ruang dan waktu yang berbeda. Pilihan baru itu jatuh pada ruang dan waktu yang disebut dengan "era kontemporer", era kehidupan manusia terkini. Era, di mana kehidupan manusia secara pelan-pelan ingin bergeser dari krisis multi dimensi, baik krisis spiritual, moral, nilai, maupun krisis humanisasi yang terjadi di era modernisme menuju ke era kebebasan dan kemandirian (post-modernisme).

Munculnya krisis multi dimensi itu ditengarahi adalah akibat sikap dan paradigma modernisme yang identik dengan jargon rasionalisme, materialisme, positivisme, empirisme dan individualisme. Sederetkarakteristik inilah yang membingkai gaya hidup mereka memiliki cara pandang generalistik, mekanistik dan sistemik. Paradigma modernitas dengan pilar kekuatan nalar rasionalismenya acapkali membawa mereka ke dalam bingkai gaya hidup absolutisme dan cenderung represif.

Sementara itu era kontemporer dengan seperangkat paradigma dan tata nilainya mengidealkan hadirnya corak paradigma keagamaan dan kehidupan baru yang jauh berbeda dan bahkan berlawanan arah dengan gaya hidup sebelumnya. Corak paradigma keagamaan itu disebut dengan paradigma post-modernime. Pemahaman keagamaan yang berpijak pada cara pandang relatifistik, subyektifistik, pluralistik, dekonstruktifistik, dan partikularistik. Paradigma pemahaman keagamaan yang menolak sikap kemapanan, grand Theory, status quo, cara berpikir final dan hal-hal lain yang sejenis. Meminjam istilah Komarudin $\mathrm{H}$ idayat, era post-modernisme adalah era yang mengerahkan sejumlah daya kekuatan, baik fisik maupun psikis untuk melakukan pemberontakan terhadap keangkuhan epistemologis yang absolustik dan represif. ${ }^{14}$

\footnotetext{
${ }^{14}$ Samsul Arifin.,dkk., Spiritualisasi Islam dan Peradaban Masa Depan (Yogyakarta: Sipress, 1996), 33.
} 
Efek langsung dari paradigma ini adalah tidak terlihatnya petunjuk hidup maupun petunjuk pelaksanaan (juklak) kehidupan yang baku. Bagi masyarakat awam yang tidak memiliki otoritas dan kapabilitas ilmu pengetahuan secara tidak langsung terkena imbas paradigma ini. Tidak sedikit di antara mereka yang merasakan keresahan serupa sebagaimana keresahan yang dialami oleh era sebelumnya, yaitu modernisme. Mereka telah kehilangan arah dan pijakan hidup karena derasnya dinamika pemikiran keagamaan maupun yang lainnya yang saling counter-mengcounter pandangan, saling melemahkan gagasan antara satu dengan yang lain. Sehingga tidak satupun terdapat gagasan yang dinilai bisa diikuti.

Tradisi ini berjalan secara dinamis dan inovatif, sementara tawaran teoretik baru yang kokoh belum dijumpai eksistensinya. Bagaikan buah simalakama, bermaksud mengikuti pandangan baku tidak mungkin terjadi karena perhelatan wacana di antara mereka saling menajam (relatif-dekonstruktif), sementara menunggu otoritas kemampuan nalar individualnya masih jauh dari kemungkinan, lantaran kering referensi dan analogi. Di sinilah nilai-nilai negatif dampak postmodernisme pada satu sisi, sekalipun pada sisi lain paradigma ini telah berpotensi mengantarkan produktifitas dan kreatifitas pemikiran keagamaan dan kehidupan para elit keagamaan tertentu. Dengan demikian era ini tanpa terasa telah memberikan ruang yang sangat lebar bagi lahirnya kemandirian otoritatif masing-masing individu untuk mengkonstruk pemahaman hidup mereka (subyektif-konstruktif).

2. Sufisme: Trend Spiritualitas di Era Kehidupan Kontemporer

Keresahan dan kebingungan masyarakat awam pada satu sisi dan kecerdikan dinamis di kalangan masyarakat elit pada sisi lain sebagai imbas paradigma post-modernisme, telah membawa mereka kepada kesadaran epistemologinya masing-masing yang mereka yakini. Kesadaran ini tidak saja dalam konteks dunia non religiusitas, melainkan justru sebaliknya, yaitu adanya kesadaran nilai-nilai religiusitas yang sangat luar biasa dan beragam. Inilah yang pada gilirannya problema spiritualitas post-modernisme telah memanifestasi dengan wajah yang sangat heterogen. Tidak sebagaimana problem spiritualitas yang terjadi sebelumnya yang cenderung homogen, sekalipun tetap mengalami proses evolutif dari generasi ke generasi.

Sesuai dengan watak epistemologinya yang cenderung merangkul heteroginitas, paradigma post-modernisme dalam konteks yang sama juga dituntut mencari jati dirinya di tengah paradigma yang serba relatif dan subyektif itu. Tuntutan-tuntutan tersebut secara perlahan berhasil mengkonstruk jargon heterogenitas itu menjelma menjadi sikap absolusitas baru yang represif. Yang membedakan keduanya adalah bahwa sikap modernisme lebih menampakkan absolusitas di tengah homogenitas, sementara post-modernisme lebih menunjukkan sikap absolusitas di tengah heterogenitas. Efek paradigma pertama berimbas secara komunal, sedangkan efek yang kedua bermuara kepada individual atau pada kelompok kecil tertentu. Dengan demikian resiko sosial paradigma modernisme dianggap lebih kecil dan relatif tidak berimplikasi secara makro dalam kehidupan. Sebaliknya paradigma postmodernisme jauh akan berdampak lebih besar mengingat keragaman dan pluralitas epistemologinya akan membawa resiko sendiri-sendiri.

Alasan inilah yang menyebabkan trend spiritualitas (sufisme) pada era ini (kontemporer) marak dan bermunculan di mana-mana, tentu dengan trend spiritualitas yang diusung dari 
latar cara pandang yang heterogen pula. Kemunculan trend spiritualitas di era ini lebih dimotivasi pada pencarian keseimbangan dan kepastian suatu kebenaran dengan cara barunya, yaitu lewat spiritual (nalar irfani) dan bukan lewat logika penalaran relatif-spekulatif (nalar burhani). Pencarian kebenaran melalui logika penalaran relatif-spekulatif yang selama ini mereka lakukan, bagi para spiritualis dianggap tidak mampu memberikan jawaban yang tepatmenurut logika nalar keagamaan.

Namun demikian karena heterogenitasnya, karakteristik para spiritualis (sufis) dalam konteks post-modernisme ini tidak menutup kemungkinan akan menampakkan karakteristik yang berbeda-beda pula. Karakteristik tersebut di antaranya ada yang merujuk pada model sufisme klasik, pertengahan, maupun modern, yang pada giliran selanjutnya juga akan berdialektika secara epistemologis dengan simbol-simbol trend pemikiran keagamaan postmodernisme yang berkembang pada saat ini. Trend keagamaan itu antara lain adalah warisan pemikiran tradisionalis, fundamentalis, radikalis, modernis, neo-modernis, liberalis dan lain sebagainya. Oleh karena itu sufisme dalam konteks kehidupan kontemporer ini akan menunjukkan model keragamannya dengan tipologinya sendiri-sendiri. Dengan kata lain implementasi gerakan sufisme dalam masyarakat kontemporer akan menampakkan suatu gerakan keagamaan yang merepresentasi trend pemikiran keagamaan di atas.

Representasi gerakan sufisme yang berkolaborasi dengan trend pemikiran keagamaan tersebut tidak menutup kemungkinan akan memanifestasi dalam bentuk dan kategorinya yang berbeda-beda. Kategori baru itu antara lain adalah asketisme-tradisionalis, ortodoksirevivalis (fundamentalis-radikalis), ortodoksi-tradisionalis, teosofi-liberalis, dan neo-sufismemodernis. Sebab gerakan sufisme yang mengalami proses kolaborasi dengan trend tipologi pemikiran di atas, pada hakikatnya juga merupakan faham yang masing-masing merasakan dan menyadari secara totalitas tentang keberadaan Tuhannya, suatu kesadaran yang berimplikasi secara langsung terhadap kesadaran nilai-nilai sosialnya. ${ }^{15}$

Hanya saja wujud kesadaran sosialnya pun juga akan tampil dengan kemasan yang berbeda-beda, adakalanya tampil dengan sikap radikalnya (keras) namun juga ada yang tampil dengan sikap humanisnya (luwes). Model yang pertama acapkali dipraktikkan oleh kelompok fundamentalis, radikalis, sementara yang kedua cenderung dipraktikkan oleh kelompok liberalis. Dengan demikian, dari sekian corak sufisme yang mentradisi dalam kehidupan kontemporer ini, tidak ada seorang pun yang memiliki otoritas penuh untuk memberikan penilaian-penilaian pejoratif terhadap kelompok tertentu. Sebab masing-masing corak telah memiliki landasan paradigmatik yang kokoh dengan seperangkat sistem nilai keagamaan maupun logika penalaran yang melandasinya.

Dari pembacaan historis corak sufisme di atas, dapat digambarkan corak sufisme kontemporer sebagai berikut.

a. Asketisme-Tradisionalis

Corak spiritualitas ini cenderung bernostalgia dengan gaya kehidupan sufisme klasik yang belum memperoleh bentuknya secara legal-formal. Corak sufisme yang berusaha

${ }^{15}$ Abu al-Wafasal-G hanimi al-Taftazani, Madkhal Ila al-Tasawwuf al-Islami, 4-5. 
melakukan upaya-upaya kontras terhadap tradisi sekuler para birokat yang bergaya hidup hedonis-profanistik pada masanya. Sikap ini memiliki relevansi esoterik dengan cara pandang kelompok tradisionalis, utamanya yang hidup di kalangan masyarakat pedesaan, jauh dari kehidupan hedonis. Trend sufisme ini banyak direpresentasi oleh para kyai desa maupun kota yang masih kuat tradisi qanaahnya. Mereka tidak tertarik dalam dunia politik praktis. Mereka adalah kumpulan orang-orang yang tertarik pada tradisi salaf al-salih yang peka terhadap lingkungan di mana mereka berada. Sikap dan perilaku mereka cenderung ramah, humanis, peka lingkungan. Cara pandang mereka terhadap kehidupan keduniawian tidak terikat oleh hal-hal yang materialistik semata, melainkan sebaliknya, yaitu pandangan yang senantiasa berorientasi pada masalah-masalah ukhrawi. Oleh karenanya komunitas ini mayoritas tidak memiliki kekayaan materi, melainkan kekayaan hati, penuh pemaaf, penuh kesabaran, penuh qanaah, penuh syukur, penuh kasih sayang dan lain sebagainya.

b. Ortodoksi-Revivalis (fundamentalis-radikalis) dan Ortodoksi-Tradisionalis

Corak spiritualitas ortodoksi-revivalis ini cenderung bergaya hidup legal-formalistiktekstualis. Perilaku sufisme yang dibangun di atas landasan pola berpikir teologis dan fiqih. Gerakan sufisme ini bercita-cita memotret kembali tradisi Rasul, sahabat dan para tabi' in untuk dihidupkan kembali ruh keagamaannya. Oleh sebab itu sufisme model ini adalah sufisme yang terjebak dalam tataran simbolis-formalistik. Agama hanya dipahami sebatas pada dimensi kulitnya dan bukan isinya. Tanpa terasa semua perilaku mereka telah diwarnai dengan budaya kehidupan rasul, sahabat, dan tabi'in. Nalar berpikirnya dipandu oleh dua sumber dalam Islam, yaitu al-Q ur'an dan al-H dith. Model pemahaman keagamaan seperti inilah yang membuatnya sulit beradaptasi dengan konteks sosio-kulturalnya.

Sikap hidup mereka di masyarakat kurang menampakkan pertimbangan-pertimbangan yang menyentuh dimensi emosionalnya, melainkan didominasi oleh aspek-aspek teologis dan shar'inya. Tentu saja sikap dan perilaku mereka jauh berbeda layaknya para sufisme yang lain. Sufisme ortodoksi dengan corak pemikiran fundamental dan radikalnya, benarbenar telah mengkonstruk gaya hidup mereka menjadi hitam putih. Sufisme yang sedianya menjadi contoh akhlaq, kini telah berubah menjadi aliran yang melakukan peran-peran penilaian subyektif dan terkesan sangat represif. Corak kehidupan yang berbeda dari kelompoknya tidak jarang telah memperoleh penilaian tendensius. Kadang mereka dituduh sebagai kelompok kafir, bid'ah, khurafatdan takhayyul. Sementara hanya kelompoknyalah yang paling memiliki tingkat kebenaran yang hakiki. Tradisi ini tidak jarang telah melahirkan truth claim, bahwa kebenaran hanyalah berada pada kelompoknya.

Trend sufisme ini pada akhirnya lebih disibukkan pada upaya-upaya penilaian perilaku kegamaan terhadap komunitas lain, dibanding upaya-upaya pengembangan komunitasnya sendiri. Trend sufisme ini banyak bermunculan dari gerakan keagamaan para mahasiswa, utamanya dari Perguruan Tinggi Umum yang basic pemahaman keagamaannya relatif masih lemah. Sufisme ini memiliki komitmen tinggi untuk menerapkan nilai-nilai Islam dalam kehidupannya. Islam bagi mereka bukanlah agama teori melainkan agama aplikasi. Oleh karena itu siapa saja yang memiliki ilmu pengetahuan agama yang 
tinggi tetapi tidak diamalkan hal itu bagaikan pohon yang tidak berbuah.

Sedangkan ortodoksi-tradisionalis lebih menekankan pada sikap tasamuhnya. Sikap ortodoksi-tradisionalis ini betul-betul memosisikan pahamnya berada pada posisi moderat. Tidak terlalu masuk dalam dunia asketisme yang tanpa tahu menahu masalah-masalah dunia, demikian juga tidak terlalu masuk dalam ranah legal formal, segala sesuatunya serba diukur dengan ukuran-ukuran norma teks shar'i>Inilah yang membuat pola hidup sufisme ortodoksi-tradisionalis ini bersikap arif, moderat, yaitu mempertemukan dua kepentingan, baik dunia maupun akhirat dianggap sama-sama pentingnya. Model gaya kehidupan ini mayoritas diwakili oleh kelompok yang memiliki dua kecerdasan sekaligus, yaitu kecerdasan hati (emosi) dan kecerdasan intelektual (shar'ił. Kelompok masyarakat Muslim yang didewasakan lewat dunia pesantren salaf dan modern. Di antara beberapa contoh trend sufisme model ini adalah Nurcholis Madjid, Abdurrahman Wahid dkk.

c. Teosofi-liberalis

Trend sufisme ini banyak disebut sebagai tasawuf falsafi atau wacana. Mereka berusaha membangkitkan kesadaran akan adanya Tuhan melalui proses berpikir spekulatif teoritis. Model sufisme ini, banyak lahir dari kelompok muda Muslim terpelajar yang kritis dan dinamis dengan pendekatan nalar filsafat burhaninya. Mereka yang masuk dalam kategri sufisme ini adakalanya yang murni berangkat dari dominasi filsafatnya, demikian juga adakalanya yang berangkat dari nalar teks keagamaan yang metode berpikirnya menggunakan nalar burhani. Model yang pertama biasanya muncul dari mereka yang tidak memiliki latar piranti linguistik yang kuat (kitab kuning), sementara model yang kedua muncul dari komunitas pemuda Muslim yang memiliki multi pendekatan, baik bahasa maupun filsafat. Yang termasuk dari gerakan sufisme ini adalah mereka yang tergolong dalam kelompok Islam Liberal. Mereka pada hakikatnya ingin mengadaptasikan Islam ke dalam konteks pemahaman global. Oleh karena itu bentuk kepedulian model keberagamaan sufisme ini adalah adanya visi yang universal mengenalkan ajaran Islam dalam skala global. Dengan demikian mereka berupaya melakukan pembacaan teks keagamaan Islam tersebut dalam kerangka kontemporer (post-modernisme).

d. Neo-Sufisme-Modernis.

Munculnya gerakan neo-sufisme ini pada hakikatnya didorong oleh komunitas puritanis yang bersemangat untuk melakukan tugas-tugas pemilahan kembali Islam dari kontaminasi perilaku khurafat, takhayyul dan bid'ah. Mereka yang termasuk dalam kategori sufisme ini adalah mereka yang menjunjung tinggi jargon kembali kepada al-Q ur'an dan hądith. Indikasi kesadaran spiritualitas dari sufisme ini adalah adanya komitmen yang tinggi untuk kembali kepada Allah melalui ajaran orisinalnya, yaitu al-Qur'an dan al-H \&dith. Semua isme sufi yang dipahami dari awal hingga akhir pada hakikatnya telah menggambarkan akan adanya nilai-nilai spiritualitas ketuhanan pada setiap corak sufis tersebut, sekalipun berbeda-beda pendekatannya. A tas dasar inilah sufisme kontemporer telah tampil dengan nilai-nilai esoteris yang serupa sekalipun dengan model ritualitas (eksoteris) yang sedikit berbeda. Yang jelas sufisme telah berhasil mencetak tokoh-tokoh besar dalam perhelatan sejarah sufi. 


\section{Kesimpulan}

Proses evolusi sufisme dari periodesasi ke periodesasi berikutnya bukanlah tanpa makna. Perubahan dari waktu ke waktu dengan seperangkat latar sosio-kulturalnya, telah mengindikasikan bahwa sufisme dalam perspektif historis memiliki catatan sejarah yang penting. Nilai-nilai penting dalam catatan sejarah itu antara lain terlihat pada peran-peran kritis mereka, baik terhadap para birokrat yang telah menyimpang jauh dari nilai-nilai Islam maupun budaya sekuler yang menghegemoni epistemologi Islam. Sufisme dengan ragam tampilan coraknya, masing-masing memiliki kontribusi sosiologis yang tidak kecil dalam konteks sejarah. Selain itu gerakan sufisme dengan pola perubahannya yang sangat dinamis juga menggambarkan bahwa sufisme dalam konteks sejarah tampil dengan tradisi dinamis dan inovatifnya, tidak mengenal lelah dalam membawa misi spiritualitasnya. Sufisme adalah paham yang tidak bisa dipisahkan dengan model keagamaan kapan pun dan bagaimanapun.

Oleh karena itu setiap perubahan situasi dan kondisi, sufisme akan membawakan dirinya sesuai dengan situasi dan kondisi yang ada. Demikian pula dari situasi dan kondisi modernism misalnya ke post-modernisme, sufisme juga akan tampil dengan tradisi spiritual ala postmodernismenya. Hal ini terbukti bahwa ketika seseorang mencapai titik kegagalan spiritual di era modernism karena sikap absolusitas di tengah homogenitas, maka manusia segera melakukan pelarian menuju ke post-modernisme yang dinilai mampu memberikan ruang lebar bagi kebebasan nalar keagamaannya. Namun ternyata kebebasan pun tetap tidak mampu menjawab problema masyarakat pasca modern, lantaran semua grand teori apapun ketika itu tidak ada yang kebal kritik. Dengan demikian upaya pencarian jati diri atau kemapanan, pada saat itu secara perlahan sangat dibutuhkan. Oleh karena itu sikap absolusitas yang mereka hindari pun pada akhirnya dijumpai kembali dalam suasana yang berbeda. Semula menghindari sikap absolusitas di tengah homogenitas (modernisme), pada akhirnya bertemu kembali dengan sikap absolusitas di tengah heterogenitas (post-modernisme).

\section{Daftar Rujukan}

Abu al-Wafa al-G hanimi al-Taftazani. Madkhal ila al-Tasłwwuf. Kairo: Dasal-Thaqa汸, 1974. Abdul Karim al-Q usyairi. al-Risalah al-QusH airiyah . Kairo: TP. $1330 \mathrm{H}$.

Ibn Taimiyah, al-Sufiyah wal-Fuqara's diedit oleh Rasyid Ridla, al-Manar, Kairo, $1348 \mathrm{H}$. Ibrahim Basyuni. Nash‘ al-Tasłwuf fi al-Islam . Kairo: Dasal-Ma‘akif,1969.

Bernd Radtke, "Konsep Wilayah dalam Sufisme Awal” dalam Warisan Sufi: Sufisme Persia Klasik dari Permulaan Hingga Rumi (700-1300). Terj. G afna Raizha Wahyudi. Yogyakarta: Pustaka Sufi, 2002.

R.A. Nicholson. The Mystic of Islam .London: Kegan Paul,1966.

Rivay Siregar. Tasawuf: Dari Sufisme Klasik ke Neo Sufisme. J akarta: Raja G rafindo Persada, 2002. Samsul Arifin., dkk. Spiritualisasi Islam dan Peradaban Masa Depan. Yogyakarta: Sipress. 